\title{
Effect of probiotic additives and Bacillus licheniformis inclusion in the diet on broiler growth
}

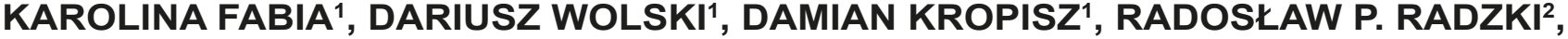 \\ MAREK BIEŃKO², SYLWIA SZYMAŃCZYK², ALEKSANDRA KIMICKA², \\ MAŁGORZATA MANASTYRSKA²
}

\author{
${ }^{1}$ Research and Development Centre in Potok, Ekoplon Sp. z o.o. Sp. K., Grabki Duże, Poland \\ ${ }^{2}$ Department of Animal Physiology, Faculty of Veterinary Medicine, University of Life Sciences in Lublin, \\ Akademicka 12, 20-950 Lublin, Poland
}

Fabia K., Wolski D., Kropisz D., Radzki R. P., Bieńko M., Szymańczyk S., Kimicka A., Manastyrska M. Effect of probiotic additives and Bacillus licheniformis inclusion in the diet on broiler growth

\section{Summary}

The withdrawal of antibiotic growth stimulators as of 1 January 2006 in the European Union countries has forced the search for alternative solutions to improve the health and productivity of poultry. The poultry industry also faces the challenge of developing alternative feeding systems with the restriction or exclusion of coccidiostats. One of them is the use of probiotic strains as feed additives. This study aimed to determine the effect of the use in compound feed of a probiotic containing Bacillus licheniformis on rearing rates and postmortem performance of broiler chickens. The experiment was performed on 8012 unsexed broiler chickens of the Ross 308 line divided into four equal groups. The experimental factors were the addition of a probiotic containing Bacillus licheniformis bacteria and the addition of a coccidiostat. The introduction of probiotic bacteria into compound feed did not increase the body weight of birds, in particular, control weights, and at the end of rearing, but it decreased the feed conversion rate (FCR) and mortality. Addition of probiotic in compound feed did not have a significant effect on bird muscle. The mean weight of pectoral muscle between control $(\mathrm{C}+, \mathrm{C}-)$ and study $(\mathrm{C}-\mathrm{BL}, \mathrm{C}+\mathrm{C}-\mathrm{BL})$ groups did not show statistically significant differences; however, the highest mean weight of the evaluated parameter was visible in the $\mathrm{C}+$ group $(0.665)$ and the lowest in the C-BL group (0.623). Similarly to the mean weight of the carcass, also in the mean weight of thigh muscles, the lowest statistically significant values were observed in chickens belonging to the C+C-BL group (vs. C-; $P<0.05)$. Based on the obtained results, it can be acknowledged that the probiotic bacteria Bacillus licheniformis in broiler feed can be a good feed additive to replace antibiotics/coccidiostats. This probiotic has a positive effect on the overall health of birds, contributes to better use of nutrients and stimulates growth and development of broiler chickens.

Keywords: broiler chickens, probiotics, feed additives

Withdrawal of antibiotic growth stimulants has forced the search for alternative solutions for improving the health and productivity of poultry. One of these is the administration of probiotic strains. These additives can occur in the form of monocultures, as well as mixtures of various strains (17). Live cultures of microorganisms in the diet stimulate the activity of intestinal enzymes, the secretion of bacteriocins with antibacterial properties, acidification of the intestinal contents and local immunity within the gastrointestinal mucosa $(11,15)$. Probiotics induce the effects of stimulating the intestinal immune response by activating Toll-like receptors (TLRs) in the intestinal epithelium and modulating cytokine production in response to $\mathrm{NF}-\kappa \mathrm{B}$ pathway signaling $(22,30)$. The addition of probiotic bacteria to poultry feed causes the phenomenon of competitive displacement (32) of enteropathogens by adhesins of non-pathogenic bacteria, which after binding to TLR receptors of epithelial cells induce a non-pathogenic immune response in the small intestine (25). The beneficial effect of probiotic strains has been confirmed in many studies using various animal species $(9,24,27)$. Studies on poultry confirm that the feed additive in the form of Bacillus subtilis bacteria increases bird resistance to colonization of the gastrointestinal tract by $E$. coli and reduces the presence of pathogenic microorganisms E. coli, Salmonella enteritidis and Clostridium perfingens in the spleen, caecum and liver in young animals $(18,19)$. The addition of Bacillus subtilis and Bacillus licheni- 
Tab. 1. Arrangement of experimental diets

\begin{tabular}{|l|c|c|c|c|}
\hline \multicolumn{1}{|c|}{ Addition } & Positive control - C+ & Negative control - C- & Negative control + probiotic - C-BL & $\begin{array}{c}\text { Starter: Positive control + probiotic, other feeds: } \\
\text { Negative control + probiotic - C+C-BL }\end{array}$ \\
\hline Coccidiostat & + & - & - & $+/-$ \\
Probiotic & - & - & + & + \\
\hline
\end{tabular}

Explanation: - no, + yes

formis bacteria to the diet of turkeys has a positive effect on the results of turkey rearing and significantly improves their final body weight and average weight gain (13). Moreover, the use of probiotics in the feeding of piglets reduces their mortality in the critical period around weaning (26) and effectively reduces diarrhoea caused by E. coli in weaned pigs (20), while improving the body's defense functions through growth production of $\operatorname{IgM}$ and $\operatorname{IgA}$ antibodies, as well as Th1, Th2, TNF- $\alpha$ cytokines (39). In the feeding of calves, the addition of Lactobacillus and Bifidobacterium bacteria enhances rearing results, reduces mortality and additionally reduces the percentage of respiratory diseases and diarrhoea (36). The effect of the abovementioned activities is the improvement of the health and production performance of animals.

The research aimed to determine the effect of the use of a probiotic containing Bacillus licheniformis bacteria in feed on rearing rates and post-slaughter results of broiler chickens.

\section{Material and methods}

The experiment used 8012 unsexed broiler chickens from the Ross 308 line. The day-old chicks were from the same hatchery and parent stock. The experimental factors were: the addition of a probiotic in the amount of $500 \mathrm{~g} / 1000 \mathrm{~kg}$ of the feed mixture containing Bacillus licheniformis bacteria $\left(1 \times 10^{9} \mathrm{CFU} / \mathrm{g}\right)$ (Novus Int., Saint Charles, MO, USA) and the addition of the coccidiostat - sodium salinomycin - in the amount of $90 \mathrm{mg} / \mathrm{kg}$ of the mixture. Two control groups and two experimental groups were created in the design given in Table 1.

All chickens were divided into four equal groups. Within the group, twelve repetitions of 167 birds were identified. The chickens were reared for 42 days in metal pens under standard conditions, with the use of climate control technology and respect to animal welfare. Peat with the addition of wood chips was used as a mulch. Throughout the rearing period, the birds were fed ad libitum with granulated starter mixes for the first 10 days, and then from day 11 to 23 with grower 1 mix, from day 24 to 33 with grower 2 mix and over 33 days with finisher mix (Ross broiler managment handbook. Aviagen.com, $2018 ; 12,21)$. All feed mixtures used during the experiment were produced in the feed factory Ekoplon Sp. z o.o. Sp. K. (Grabki Duże, Poland), using the same raw materials. To avoid accidental loading of the feed with probiotics, feeds for $\mathrm{C}+$ and $\mathrm{C}$ - birds were always produced first, before the feeds for groups with added probiotic. The feed mixtures were balanced according to nutritional recommendations (33). The matrix of the probiotic nutritional values and the nutrient content of the feed mixtures are presented in Tables 2-4. During the experiment, the bodyweight of the chickens was monitored on the $1^{\text {st }}, 7^{\text {th }}, 14^{\text {th }}, 21^{\text {st }}, 28^{\text {th }}$, $35^{\text {th }}$ and $42^{\text {nd }}$ days of rearing. In addition, on the $21^{\text {st }}$ day of the experiment, further weighing of 2016 chickens from four groups from three randomly selected pens, was carried out for flock uniformity analysis. On this basis, the CV variation of the coefficient was calculated. During the experiment, the consumption of feed by each group for the individual phases of feeding and the final consumption were recorded. The feed conversion rate (FCR) was reduced by an appropriate correction resulting from the weightings lost during the experiment, the chickens and the conversion of their respective feed consumed. The number of dead and selected birds in each group and their health status were checked daily. The obtained results were the basis for calculating the European efficiency index (EPI) according to the formula provided by Świątkiewicz and Koreleski (35) and the European production efficiency factor (EPEF) based on the formula provided by Shareef et al. (31). After the completion of the feeding experiment in the farm laboratory, five randomly selected chickens from each group were dissected and the body weight, pectoral and thigh muscle weights were determined. The obtained results were statistically verified according to the one-way analysis of variance (ANOVA) model. If statistically significant differences were found between the groups, Tukey's post hoc tests were performed. Statistical analysis was performed using Statistica 13.0 PL (Statsoft, Tulsa, USA computer program).

\section{Results and discussion}

The content of nutrients in complete mixtures (Tab. 2, 3) was at the level recommended for fattening

Tab. 2. Matrix of nutritional values of a probiotic with the participation of Bacillus licheniformis bacteria

\begin{tabular}{|l|c|c|c|c|}
\hline \multicolumn{1}{|c|}{ Ingredient (\%) } & $\begin{array}{c}\text { Starter } \\
\text { (1-10 days) }\end{array}$ & $\begin{array}{c}\text { Grower 1 } \\
\text { (11-23 days) }\end{array}$ & $\begin{array}{c}\text { Grower 2 } \\
\text { (24-33 days) }\end{array}$ & $\begin{array}{c}\text { Finisher } \\
\text { (over 33 days) }\end{array}$ \\
\hline Crude protein & 1708.79 & 1592.26 & 1518.86 & 1481.45 \\
\hline Dig. Lysine & 92.25 & 79.23 & 74.21 & 70.63 \\
\hline Dig. Thr & 69.50 & 64.52 & 60.91 & 58.42 \\
\hline Dig. Methionine (\%) & 24.21 & 23.48 & 22.45 & 21.86 \\
\hline Dig. Cysteine & 36.27 & 35.33 & 33.69 & 32.81 \\
Dig. M+C & 60.48 & 58.81 & 56.14 & 54.67 \\
\hline Dig. Tryptophan & 19.37 & 17.75 & 16.61 & 15.90 \\
\hline Dig. lle & 59.84 & 59.46 & 56.33 & 54.37 \\
\hline Dig. Valine & 83.49 & 71.64 & 68.09 & 65.98 \\
\hline Dig. Arginine & 92.80 & 87.47 & 81.12 & 75.78 \\
\hline ME (kcal/kg) & 56817.54 & 52029.45 & 49000.67 & 46740.99 \\
\hline
\end{tabular}

Explanation: ME - Metabolizable energy; Dig. - digestible 
Tab. 3. Content of nutrients in the compound feed in the $\mathrm{C}+$ and $\mathbf{C}$ - groups

\begin{tabular}{|l|c|c|c|c|}
\hline Ingredient (\%) & Starter & Grower 1 & Grower 2 & Finisher \\
\hline Protein & 21.791 & 20.568 & 19.474 & 18.767 \\
Fat & 5.280 & 5.927 & 72.900 & 7.935 \\
Fiber & 3.233 & 3.332 & 3.358 & 3.480 \\
Ash & 5.137 & 4.594 & 4.176 & 3.918 \\
Lysine & 1.335 & 1.260 & 1.194 & 1.139 \\
Methionine & 0.623 & 0.595 & 0.564 & 0.538 \\
Calcium & 0.800 & 0.650 & 0.560 & 0.500 \\
Phosphorus & 0.579 & 0.525 & 0.477 & 0.459 \\
Sodium & 0.162 & 0.152 & 0.142 & 0.142 \\
\hline
\end{tabular}

chickens in all rearing periods (33). The introduction of Bacillus licheniformis bacteria into the feed mixtures did not increase the bodyweight of the chickens in individual control weighings and at the end of rearing (Tab. 4). Taking into account the $\mathrm{C}-\mathrm{BL}$ and $\mathrm{C}+\mathrm{C}-\mathrm{BL}$ groups, the group with the addition of coccidiostatic in the starter-type feed in individual control weights (days 7, 14, 21, 28, 35) showed a higher body weight compared to a group without the addition of a chemotherapeutic agent (Fig. 1). The highest mean body weight on day 42 of the chickens' life was found in the $\mathrm{C}$ - group and the lowest statistically significant values of the discussed parameter were found in the $\mathrm{C}+\mathrm{C}-\mathrm{BL}$ group (vs. group $\mathrm{C}-; \mathrm{P}<0.05$ ). Chickens from $\mathrm{C}-\mathrm{BL}$ and $\mathrm{C}+$ groups showed the most similar mean body weight values. Data from literature show that Brzóska et al. (4), Mikołajczyk et al. (23), Klocek et al. (16) and Angel et al. (1) also did not note a significant effect in the adding of probiotics on bird growth and final body weight. Other researchers found that the dietary supplementation of $3 \mathrm{~g} / \mathrm{kg}$ of $B$. licheniformis - fermented products in broilers increased their body weight during the entire feeding period (7). Both the control and research groups were characterized by a low value of the variation of coefficient $(\mathrm{CV}<25 \%)$, which indicates
Tab. 4. Effect of feed additives containing Bacillus licheniformis on the body weight of broiler chickens (mean $\pm \mathrm{SD}$, $\mathbf{n}=\mathbf{2 0 0}$ in each group)

\begin{tabular}{|c|c|c|}
\hline Weighing day & Group & Body weight $(g) \pm S D$ \\
\hline \multirow{4}{*}{0} & C+ & $40.0 \pm 0.00$ \\
\hline & C- & $40.0 \pm 0.00$ \\
\hline & C-BL & $40.0 \pm 0.00$ \\
\hline & $\mathrm{C}+\mathrm{C}-\mathrm{BL}$ & $40.0 \pm 0.00$ \\
\hline \multirow{4}{*}{7} & C+ & $207.75 \pm 1.58^{c}$ \\
\hline & C- & $200.08 \pm 1.76$ \\
\hline & C-BL & $195.50 \pm 3.55^{\mathrm{ad}}$ \\
\hline & $C+C-B L$ & $209.00 \pm 2.15^{c}$ \\
\hline \multirow{4}{*}{14} & C+ & $513.50 \pm 7.28^{c}$ \\
\hline & C- & $514.75 \pm 7.12^{\mathrm{c}}$ \\
\hline & C-BL & $484.67 \pm 10.29 \mathrm{ab}$ \\
\hline & $C+C-B L$ & $498.67 \pm 12.14$ \\
\hline \multirow{4}{*}{21} & $\mathrm{C}_{+}$ & $1003.8 \pm 22.28^{b c}$ \\
\hline & C- & $951.25 \pm 13.36^{a}$ \\
\hline & C-BL & $946.25 \pm 11.93^{\mathrm{a}}$ \\
\hline & $\mathrm{C}+\mathrm{C}-\mathrm{BL}$ & $968.67 \pm 18.39$ \\
\hline \multirow{4}{*}{28} & $C_{+}$ & $1669.0 \pm 39.23^{b c}$ \\
\hline & C- & $1541.3 \pm 29.26^{a}$ \\
\hline & C-BL & $1525.2 \pm 29.45^{\mathrm{a}}$ \\
\hline & $\mathrm{C}+\mathrm{C}-\mathrm{BL}$ & $1585.3 \pm 30.32$ \\
\hline \multirow{4}{*}{35} & C+ & $2269.0 \pm 35.30$ \\
\hline & C- & $2269.2 \pm 49.50$ \\
\hline & C-BL & $2145.8 \pm 43.25$ \\
\hline & $\mathrm{C}+\mathrm{C}-\mathrm{BL}$ & $2200.0 \pm 57.30$ \\
\hline \multirow{4}{*}{42} & C+ & $2700.0 \pm 23.12$ \\
\hline & C- & $2747.0 \pm 20.69^{d}$ \\
\hline & C-BL & $2690.0 \pm 29.24$ \\
\hline & $C+C-B L$ & $2665.0 \pm 27.87^{b}$ \\
\hline
\end{tabular}

Explanations: Different superscripts letters represent statistical significance, ${ }^{\mathrm{a}} v s$. group $\mathrm{C}+,{ }^{\mathrm{b}} v s . \mathrm{C}-,{ }^{\mathrm{c}} v s$. group $\mathrm{C}-\mathrm{BL},{ }^{\mathrm{d}} v s . \mathrm{C}+\mathrm{C}-\mathrm{BL}$ at $\mathrm{P}<0.05$

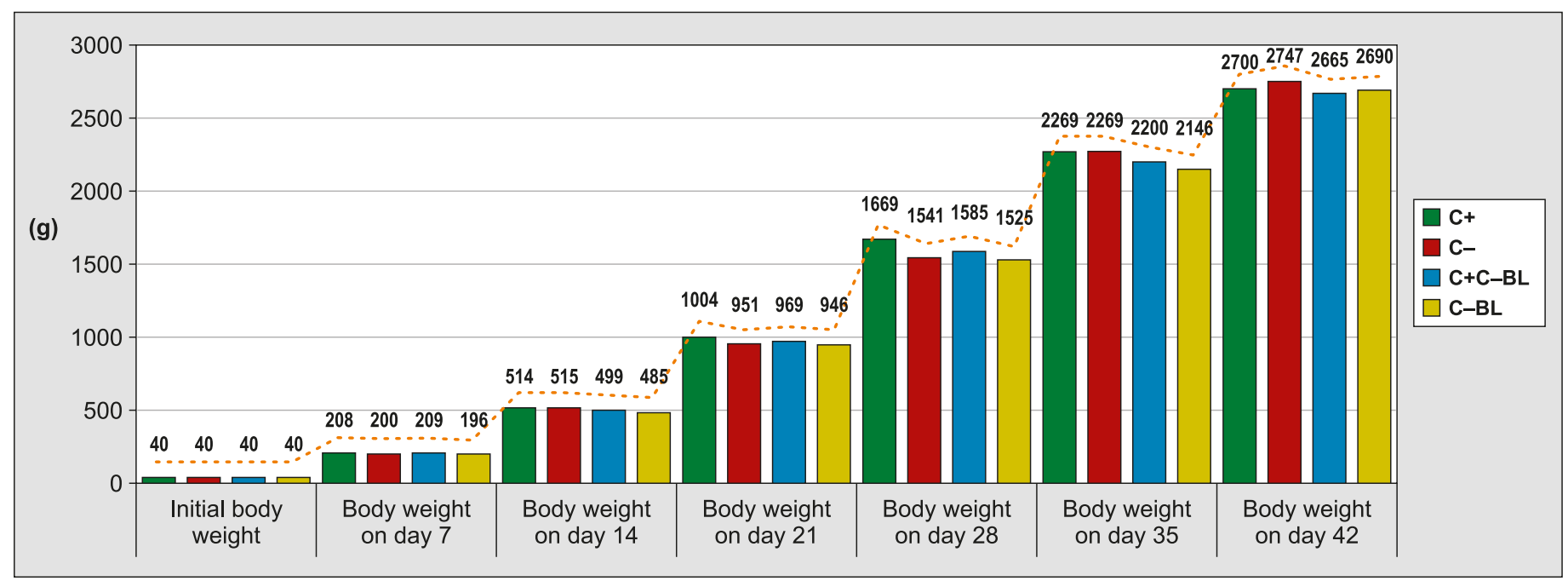

Fig. 1. The results of control and final weighing on individual days of rearing $(n=200$ in each group) 
the negligible differentiation of bodyweight of chickens in the individual groups and the homogeneity of the studied population (Tab. 5). The use of a probiotic supplement in the mixtures influenced the feed conversion ratio (FCR). The consumption of the mixture per unit of increment was lower in the research group $\mathrm{C}-\mathrm{BL}$ and $\mathrm{C}+\mathrm{C}-\mathrm{BL}$ and amounted to $1.506(\mathrm{~kg} / \mathrm{kg})$ and $1.512(\mathrm{~kg} / \mathrm{kg})$, respectively, compared to the control groups (Tab. 6). Our results confirm the findings of Hooge et al. (14), who carried out research on broiler chickens fed with fodder with the addition of a probiotic preparation including Bacillus subtilis and the findings of Zaghari et al. (38), who fed broiler chickens on a basal diet plus $0.5(\mathrm{~g} / \mathrm{kg}) \operatorname{diet} B$. licheniformis preparation $\left(1 \times 10^{9} \mathrm{CFU} / \mathrm{g}\right)$. These showed greater weight gain and a lower feed conversion rate throughout the rearing period. Moreover, Cinar et al. (8) indicated that the addition of pro/prebiotics to maize and wheat-based mixtures significantly improved the feed conversion index, as well as increased weight gain of the birds.

The effect of a lower FCR index and a higher survival rate of birds from the C-BL experimental group was a higher European poultry production index (EPI) (399.4 points) and European production efficiency factor (EPEF) (399.0 points). These indicators are used for comparative purposes for objectively testing the production effects in chickens reared for fattening of varied feeding and bird density conditions (15). Szőllösi and Szücs (34) suggest that the production of broilers is profitable only with EPEF above 300-310. In our own research, the lowest values of the EPI index were recorded in the $\mathrm{C}+$ group (385.6 points), while the EPEF in the group $\mathrm{C}+\mathrm{C}-\mathrm{BL}$ was 390.2 points. In the studies by Janoch et al. (15), the addition of Bacillus subtilis and Saccharomyces cerevisiae to the feed significantly increased the value of the EPI index. In the conducted experiment, the highest survival of chickens in the food groups was recorded in the C-BL group (98.303\%). Group C- was characterized by the highest mortality rate. Opinions on the reduction of chickens mortality by adding probiotic bacteria to the feed are divergent. The research results available in the literature are carried out in various zoohygienic conditions with the use of microorganisms with different potency on the bird's organism (37). Numerous reports confirm a significant decrease in mortality in chickens fed mixtures with the addition of probiotic bacteria $(3,4,6,10,28,37)$.

The addition of a probiotic in the feed mixes did not have a significant effect on the muscularity of broiler chickens. The mean weight of the pectoral muscle between the control $(\mathrm{C}+, \mathrm{C}-)$ and research groups $(\mathrm{C}-\mathrm{BL}, \mathrm{C}+\mathrm{C}-\mathrm{BL})$ showed no significant differences (Tab. 7). As in the case of the mean carcass weight, the significantly lowest values of the mean weight of the femurs were recorded in the chickens from the $\mathrm{C}+\mathrm{C}-\mathrm{BL}$ group (vs. $\mathrm{C}-; \mathrm{P}<0.05)$.
Tab. 5. Variation of coefficient (CV) of body weight of broiler chickens in different experimental groups $(n=504$ in each group)

\begin{tabular}{|l|r|}
\hline \multicolumn{1}{|c|}{ Group } & CV (\%) \\
\hline$C_{+}$ & 12.987 \\
C- & 13.190 \\
C-BL & 13.640 \\
C+C-BL & 13.849 \\
\hline
\end{tabular}

Tab. 6. Effect of different feed additives on broiler rearing parameters $(n=2003$ in each group)

\begin{tabular}{|l|c|c|c|c|}
\hline \multicolumn{1}{|c|}{ Group } & $\begin{array}{c}\text { FCR 41. day } \\
(\mathrm{kg} / \mathrm{kg})\end{array}$ & $\begin{array}{c}\text { Mortality } \\
(\%)\end{array}$ & $\begin{array}{c}\text { EPI } \\
(\text { points })\end{array}$ & $\begin{array}{c}\text { EPEF } \\
(\text { points })\end{array}$ \\
\hline C+ & $1.560 \pm 0.61$ & 2.140 & 385.6 & 391.3 \\
C- & $1.529 \pm 0.36$ & 2.946 & 392.8 & 398.2 \\
C-BL & $1.486 \pm 0.42$ & 1.697 & 399.4 & 399.0 \\
C+C-BL & $1.492 \pm 0.52$ & 2.347 & 386.8 & 390.2 \\
\hline
\end{tabular}

Explanations: FCR - feed conversion ratio; EPI - European efficiency index; EPEF - European production efficiency factor

Tab. 7. Effect of Bacillus licheniformis a probiotic strain on average weights of the carcass, pectoral and thigh muscle weight of broilers (mean $\pm \mathrm{SD}, \mathrm{n}=\mathbf{5}$ in each group)

\begin{tabular}{|l|c|c|c|}
\hline \multicolumn{1}{|c|}{ Group } & $\begin{array}{c}\text { Carcass weight } \\
(\mathrm{kg})\end{array}$ & $\begin{array}{c}\text { Pectoral muscle } \\
\text { weight }(\mathrm{kg})\end{array}$ & $\begin{array}{c}\text { Thigh muscle } \\
\text { weight }(\mathrm{kg})\end{array}$ \\
\hline $\mathrm{C}+$ & $2.014 \pm 0.58$ & $0.665 \pm 0.017$ & $0.407 \pm 0.047$ \\
$\mathrm{C}-$ & $2.064 \pm 0.62^{\mathrm{d}}$ & $0.627 \pm 0.024$ & $0.416 \pm 0.041^{\mathrm{d}}$ \\
$\mathrm{C}-\mathrm{BL}$ & $1.968 \pm 0.59$ & $0.623 \pm 0.020$ & $0.408 \pm 0.038$ \\
C+C-BL & $1.953 \pm 0.60^{\mathrm{a}}$ & $0.644 \pm 0.023$ & $0.401 \pm 0.042^{\mathrm{b}}$ \\
\hline
\end{tabular}

Explanations: as in Tab. 4

Our results confirmed those in earlier studies $(2,5$, $15,29)$. In chickens fed with compound feed with pro/ prebiotic preparations, no significant effect was shown on the weight of the pectoral muscles.

Based on the presented results, the probiotic bacteria Bacillus licheniformis can be considered as a good feed additive, due to its positive effect on the general health of broiler chickens. These effects contribute to better use of nutrients and stimulation of growth and development. Their addition to the feed shows great potential as an alternative to chemotherapeutic agents used both in the prevention and treatment of many diseases of animals. For two decades, there has been an increase in knowledge about the impact of probiotic bacteria, as feed supplements for farm animals, on the quality of raw materials obtained from them. Consumers' interest in the health and welfare of farm animals is also growing. However, it should be borne in mind that the use of probiotic bacteria may, unfortunately, be associated with the unfavorable phenomenon of transferring antibiotic resistance genes to other bacteria and affect the biodiversity of the environment. Therefore, there is a need for further research on probiotics that will show both the positive and undesirable effects of their 
use in the nutrition of farm animals and their impact on the body of consumers. These activities will enable the use of probiotic additives in a fully conscious, optimal and safe manner.

\section{References}

1. Angel R., Dalloul R. A., Doerr J.: Performance of broiler chickens fed diets supplemented with a direct-fed microbial. Poult. Sci. 2005, 84, 1222-1231.

2. Brzóska F.: Efektywność kwasów organicznych i synbiotyku w żywieniu kurczat rzeźnych. Med. Weter. 2007, 63, 831-835.

3. Brzóska F., Buluchewskij S., Śliwiński B., Stecka K.: The effects of lactic acid bacteria and mannan oligosaccharide, with or without fumaric acid, on chicken performance, slaughter yield and digestive tract microflora. J. Anim. Feed Sci. 2007, 16, 241-251.

4. Brzóska F., Grzybowski R., Stecka K., Pieszka M.: Wpływ mikroorganizmów probiotycznych na masę ciała kurcząt brojlerów oraz jakość tuszek. Ann. Wars. Agric. Univ. Seria Anim. Sci. 2001, 439-443.

5. Brzóska F., Pieszka M., Stecka K., Migdał W., Wessierska E., Walczycka M. Krzysztoforski K., Michalik-Rutkowska O.: Effect of Pedicoccus spp. in feed instead of antibiotic on broiler chicken body weight, mortality, slaughtertraits and meat quality. Ann. Anim. Sci. 2010, 10, 167-177.

6. Brzóska F., Śliwiński B., Stecka K., Wawrzyński M.: Efektywność bakterii probiotycznych, kwasu fumarowego i prebiotyku w żywieniu kurcząt rzeźnych. Rocz. Nauk. Zootech. 2008, 35, 173-185.

7. Chen Y. C., Yu Y. H.: Bacillus licheniformis-fermented products improve growth performance and the fecal microbiota community in broilers. Poult Sci. 2020, 99, 1432-1443.

8. Çınar M., Çatlı A. U., Küçükyılmaz K., Bozkurt M.: The effect of single or combined dietary supplementation of prebiotics, organic acid and probiotics on performance and slaughter characteristics of broilers. S. Afr. J. Anim. Sci. 2009, 39, 197-205.

9. Galus-Barchan A., Radkowska I., Szewczyk A.: Nowe spojrzenie na probiotyki w hodowli bydła. Wiad. Zootech. 2018, R. LVI, 79-84.

10. Gracia M. I., Esteve-Garcia E., Engberg R. M., Mcnab J., Lippens M. Marubashi T., Mccartney E.: Effect of a bacillary probiotic supplementation in broilers. World Poultry Sci. J. 12 ${ }^{\text {th }}$ Eur. Poult. Conf. 2006, 62, 360-364.

11. Grela E. R., Semeniuk $V$ : Consequences of the withdrawal of antibiotic growth promoters from animal feeding. Med. Weter. 2006, 62, 502-507.

12. Gussen M. de, van Middelkoop K., van Mullem K., van't Veer E.: Sygnały brojlerów. Praktyczny przewodnik prowadzenia stada kurcząt rzeźnych. Apra, 2016.

13. Hanuszewska M. A., Kozłowski K., Rouault M., Blanch A.: Effect of Bacillussubtilis and Bacillus licheniformis inclusion in turkey diets on growth performance. Animal Sci. 2018, 57, 95-101.

14. Hooge D. M., Ishimaru H., Sims M. D.: Influence of dietary Bacillus subtilis C-3102 spores on live performance of broiler chickens in four controlled pen trials. J. Appl. Poultry Res. 2004, 13, 222-228.

15. Janocha A., Milczarek A., Osek M., Turyk Z.: Efektywność bakterii probiotycznych i prebiotyku w żywieniu kurcząt brojlerów. Acta. Sci. Pol., Zootechnica 2010, 9, 21-30.

16. Klocek B., Osek M., MilczarekA., Olkowski B., Janocha A.: Wpływ probiotyku, prebiotyku i synbiotyku na wskaźniki produkcyjne i jakość mięsa kurczą brojlerów żywionych dietami na bazie dwóch zbóż (kukurydza/pszenica, pszenica/pszenżyto). Zesz. Nauk. UP Wroc., Biol. Hod. Zwierz. 2011, LXII, 243-253.

17. Kukier E., Goldsztejn M., Koziet N., Kwiatek K.: Drobnoustroje probiotyczne w żywieniu zwierząt. Pasze Przemysł. 2018, 4, 74-80

18. La Ragione R. M., Casula G., Cutting S. M., Woodward M. J.: Bacillus subtilis spores competitively exclude Escherichia coli O78:K80 in poultry. Vet. Microbiol 2001, 79, 133-142.

19. La Ragione R. M., Woodward M. J.: Competitive exclusion by Bacillus subtilis spores of Salmonella enterica serotype Enteritidis and Clostridium perfringens in young chickens. Vet. Microbiol 2003, 94, 245-256.

20. Link R., Kováč G., Pistl J.: A note on probiotics as analternative for antibiotics in pigs J. Anim. Feed Sci. 2005, 14, 513-519.

21. Mazanowski A.: Nowoczesna produkcja kurcząt brojlerów. Pro Agricola 2011.

22. Michael S. P., Jennifer T. B., Mohamed F. A., Shayan S.: Immunostimulatory properties of Toll-like receptor ligands in chickens. Vet. Immunol. Immunopathol. 2013, 152, 191-199.

23. MikołajczykJ., Rojszczak M., Grabowicz M., Piłat J.: Wpływ probiotyku L-5 na efekty produkcyjne, wydajność rzeźną i jakość produktów poubojowych kurcząt brojlerów. Ann. Warsaw Agric. Univ. Anim. Sci. 2013, 509-513.

24. Mirowski A.: Użyteczność probiotycznych bakterii w żywieniu młodych świń. Życie Wet. 2019, 94, 506-508.

25. Mizak L., Gryko R., Kwiatek M., Parasion S. Probiotyki w żywieniu zwierząt. Życie Wet. 2012, 87, 736-742.
26. Modesto M., D'aimmo M. R., Stefanini I., Trevisi P., De Filippi S., Casini L., Mazzoni M., Bosi P., Biavati B.: A novel strategy to select Bifidobacterium strains and prebiotics as natural growth promoters in newly weaned pigs. Livestock Sci. 2009, 122, 248-258.

27. Niwińska B., Furgal-Dzierżuk I., Wieczorek J.: Probiotyki w żywieniu zwierzą gospodarskich. Wiad. Zootech. 2018, R. LVI, 102-111.

28. Pietrzak D., Mroczek J., Garbaczewska A., Florowski T., Riedel J.: Wpływ wybranych dodatków do paszy o działaniu przeciwbakteryjnym na jakość mięsa i tłuszczu kurcząt. Med. Weter. 2009, 65, 268-271.

29. Ramasamy K., Norhani A., Syed J.,Wong M. C. V. L., Ho Yin Wan: Effects of Lactobacillus feed supplementation on cholesterol, fat content and fatty acid composition of the liver, muscle and carcass of broiler chickens. Anim. Res. 2006, 55, 77-82.

30. Sato K., Takahashi K., Tohno M., Miura Y., Kamada T., Ikegami S., Kitazawa $H$ : : Immunomodulation in gut-associated lymphoid tissue of neonatal chicks by immunobiotic diets. Poult. Sci. 2009, 88, 2532-2538.

31. Shareef A. M., Bayon O. S., Qubih T. S.: Correlation between broiler aflatoxicosis and European production efficiency factor. Iraqi J. Vet. Sci. 2008, 22, 49-55.

32. Shim Y. H., Ingale S. L., Kim J. S., Kim K. H., Seo D. K., Lee S. C., Chae B. J., Kwon I. K.: A multi-microbe probiotic formulation processed at low and high drying temperatures: effects on growth performance, nutrient retention and caecal microbiology of broilers. Br. Poultry Sci. 2012, 53, 482-490.

33. Smulikowska S., Rutkowski A.: Zalecenia żywieniowe i wartość pokarmowa pasz dla drobiu. IFiŻZ PAN Jabłonna, WPSA 2018.

34. Szöllösi L., Szücs I.: An Economic approach to broiler production. A case study from Hungary. Stowarzyszenie ekonomistów rolnictwa i agrobiznesu. Roczniki Naukowe 2014, XVI, 275-281.

35. Światkiewicz S., Koreleski J.: Próba zwiększenia efektywności żywieniowej mieszanki paszowej dla kurcząt brojlerów w pierwszych dniach życia. Rocz. Nauk. Zootech. 2003, 30, 121-132.

36. Timmerman H. M., Mulder L., Everts H., Van Espen D. C., Van Der Wal E., Klaassen G., Rouwers S. M. G., Hartemink R., Rombouts F. M., Beynen A. C. Health and growth of veal calves fed milk replacers with or without probiotics. J. Dairy Sci. 2005, 88, 2154-2165.

37. Timmerman H. M., Veldman A., Elsen E., Rombouts F. M., Van Der Beynen A. C.: Mortality and growth performance of broilers given drinking water supplemented with chicken-specifics probiotic. Poultry Sci. 2006, 85, 1383 -1388 .

38. Zaghari M., Sarani P., Hajati H.: Comparison of two probiotic preparations on growth performance, intestinal microbiota, nutrient digestibility and cytokine gene expression in broiler chickens. J. Appl. Anim. Res. 2020, 48, 166-175.

39. Zhang L., Xu Y. Liu H., Lai T., Ma J. L., Wang J. F. Zhu Y: Evaluation of Lactobacillus rhamnosus GG using an Escherichia coli K88 model of piglet diarrhoea: Effects on diarrhoea incidence, faecal microflora and immune responses. Vet. Microbiol. 2010, 141, 142-148.

Corresponding author: Marek Bieńko, PhD, DSc., Department of Animal Physiology, Faculty of Veterinary Medicine, University of Life Sciences in Lublin, Akademicka 12, 20-950 Lublin, Poland; e-mail: marek.bienko (a).up.lublin.pl 